\section{Nature's jewels}

\section{Colin W. Harding}

The Daguerreotype: Nineteenth-Century Technology and Modern Science. M. Susan Barger and William B. White. Smithsonian Institution Press: 1991. Pp. 252. £39.95, \$67.95.

SIR John Herschel, a man not given to hyperbole, was almost unable to contain his enthusiasm when he first saw them: "It is hardly saying too much to call them miraculous. Certainly they surpass what I could have conceived as within the bounds of reasonable expectation." The 'miracles' that Herschel had witnessed were some of the earliest examples of daguerreotypes, the first practical method of making photographs.

The daguerreotype process was announced to the world at the joint meeting of the Académie des Sciences and the Académie des Arts in Paris on 19 August 1839. Invented and named with a showman's modesty by the French artist Louis Jacques Mandé Daguerre, daguerreotypes were produced on silverplated copper sheets sensitized with iodine vapour and 'developed' in mercury vapour, producing jewel-like images that possessed a verisimilitude that comtemporary observers viewed with disbelief. Samuel Morse remarked: "The exquisite minuteness of the delineation cannot be conceived. No painting or engraving ever approached it." As an image produced solely by the agency of the forces of nature, the daguerreotype was seen not as a representation of nature but as nature itself.

Although the daguerreotype found its greatest application in commercial portraiture, it was clear from the beginning that the technique also had great potential as a scientific tool, offering a means of objective, accurate and detailed recording. The chemist Joseph Gay-Lussac realized as early as 1839 that "it is certain that through Monsieur Daguerre's invention physics is today in possession of a reagent extraordinarily sensitive to the influence of light, a new instrument which will ... furnish the nucleus around which new researches and new discoveries will be made."

The daguerreotype was to be superseded by other photographic processes by the $1850 \mathrm{~s}$, but for a while it did indeed prove to be a valuable tool in many areas of study. The question of how daguerreotype images were formed, however, remained unresolved by nineteenth-century scientists, for the technology of the daguerreotype was far in advance of the science needed to describe how the process worked and the image was formed.
Barger and White have now produced a fascinating and comprehensive book on this early photographic process from the perspective of materials scientists. Drawing on the results of more than six years of work using the latest laboratory techniques, they have succeeded in unlocking the mystery of the daguerreotype, revealing the complex interplay of chemistry and optical physics that lies behind the creation of the sublimely beautiful images. As a mixture of historical research, scientific investigation and practical advice, this is, in effect, three books in one.

The authors start with the history of the daguerreotype, tracing its invention and development. They examine how the process was used by nineteenthcentury photographers and scientists and detail early efforts to understand and

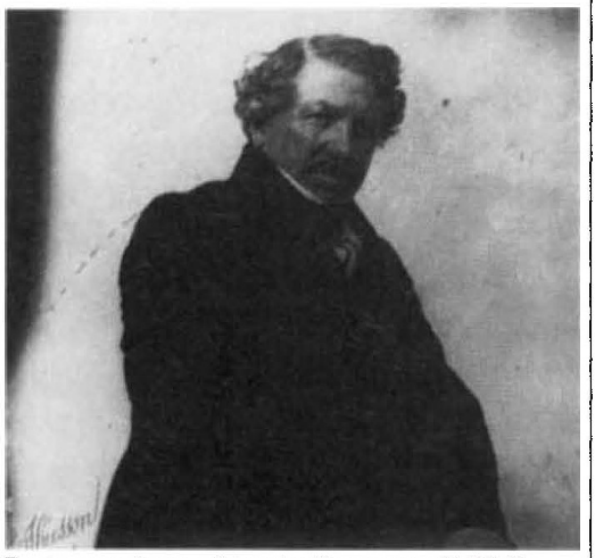

Daguerreotype of Louis Daguerre (1844).

explain the process. In the central section, the authors summarize the results of their own work into the physics and chemistry of how daguerreotype images are formed, showing that they arise from a characteristic microstructure of small silver spheres dispersed over a polished silver surface. In the final chapters, aimed primarily at conservators and curators, the authors describe both old and new methods of cleaning, preserving and displaying daguerreotypes.

Barger and White address the book to "historians of technology and science, to the curious general reader, and most important, to those charged with the care and preservation of photographs." Such is the scope of the authors' work that each of these groups will find much in the book that is useful. It is a valuable addition to photographic historiography and should stimulate similar research on other early photographic processes. Although the secrets of the daguerreotype have now been revealed, the beauty and fascination of the images remain undiminished.

Colin W. Harding is curator of the Kodak Museum at the National Museum of Photography, Film and Television, Prince's View, Bradford BD5 OTR, UK.

\section{New in paperback}

- When Did I Begin? by Norman Ford examines the concept of the human individual in history, philosophy and science. Published by Cambridge University Press, price $£ 9.95$, $\$ 16.95$.

- Between Two Worlds: Science, the Environmental Movement and Policy Choice by Lynton Keith Caldwell. Published by Cambridge University Press, price £12.95, $\$ 19.95$.

- Dover have republished The Magic of Numbers by Eric Temple Bell. First published in 1946, the book surveys the origins and influence of mathematical thought. Price £8.95, \$8.95

- Palaeobiology: A Synthesis edited by Derek E. G. Briggs and Peter R. Crowther contains more than 120 review articles. invaluable reading for all researchers and students in the field. Published by Blackwell Scientific, price $£ 34.50$.

- Penguin have published their Dictionary of Information Technology and Computer Science by Tony Gunton. Price $£ 5.99$.

- In To Save an Elephant, Allan Thornton and Dave Currey of the Environmental Investigation Agency tell how they infiltrated and exposed the illegal ivory trade. Published by Bantam, price $£ 5.99$.

\section{New editions}

- Principles of Biochemical Toxicology by J. A. Timbrell (2nd edn). Published by Taylor and Francis, price $£ 19.95$ (pbk). For a review, see Nature 302, 179; 1983.

- Understanding DNA and Gene Cloning: $A$ Guide for the Curious by Karl Drlica (2nd edn) has introductions by Bruce Alberts and Arthur Kornberg. Published by Wiley, price $£ 17.95$ (pbk).

- Nerve and Muscle by R. D. Keynes and D. J. Aidley (2nd edn) is a concise and readable introductory textbook. Published by Cambridge University Press, price £27.95, $\$ 49.95$ (hbk), £9.95, \$15.95 (pbk).

- Microbes and Man by John Postgate (3rd edn) has, since publication of the first edition in 1969, become widely acclaimed as a classic. Written for the general reader, the book is also a superb introduction for students of microbiology. Published by Cambridge University Press, price £24.95, $\$ 49.95$ (hbk), £7.95, \$15.95 (pbk).

- Sedimentary Petrology by Harvey Platt (2nd edn). Published by Freeman, price $£ 38.95$. For a review, see Nature 302, 183; 1983.

- Thinking, Problem Solving, Cognition by Richard E. Mayer (2nd edn). Published by Freeman, £29.95 (hbk), £15.95 (pbk). For a review, see Nature 308, 131; 1984.

- Volume I of High Energy Astrophysics by Malcolm S. Longair (2nd edn) provides a comprehensive introduction to particles. photons and their detection. Published by Cambridge University Press, price $£ 45$. $\$ 69.95$ (hbk), £16.95, \$34.95 (pbk). For a review, see Nature 295, 461; 1982.

- Handbook of Toxic and Hazardous Chemicals and Carcincgens by Marshall Sittig (3rd edn) is published by Noyes Data Corporation. 2 Volumes, price $\$ 197$.

- Modern Spectoscopy by J. M. Hollas (2nd edn) is aimed at students of physics and chemistry. Published by Wiley, price $£ 14.50$ (pbk), £39.50 (hbk). 